\title{
Casting new light on the chronology of the loess/paleosol sequences in Lower Austria
}

\author{
Birgit Terhorst, Christine Thiel, Robert Peticzka, Tobias Sprafke, Manfred Frechen, Florian A. Fladerer, Reinhard Roetzel, \\ Christine Neugebauer-Maresch
}

Abstract:

\begin{abstract}
This paper presents a review on recently dated sections in well-known loess/paleosol sequences of Lower Austria. The dating results indicate that there was loess deposition during the Upper Würmian Pleniglacial as recorded in the profile Joching. However, most obtained ages are older than the Last Glacial Maximum (LGM) and therefore erosional processes, which led to the removal of younger deposits can be supposed.

Soil formation between $\sim 28 \mathrm{ka}$ and $\sim 35 \mathrm{ka}$ mainly resulted in the formation of Cryosols. Hence, in the studied profiles, there is no evidence for more intense interstadial pedogenesis during this time span. This might be of particular relevance to the stratigraphy of 'Stillfried B' (sensu Fink).

The $2^{\text {nd }}$ age cluster lies between $\sim 35 \mathrm{ka}$ and $\sim 57 \mathrm{ka}$ i. e. the Middle Pleniglacial (Würmian) and is dominated by loess deposits intercalated with different Cryosols. This period is also characterized by colluvial processes.

There is a significant hiatus between $\sim 57 \mathrm{ka}$ and $\sim 106 \mathrm{ka}$, a fact which might be due to long lasting and intensive erosional processes in the study areas. The oldest measured age of the Last Glacial is $106 \pm 12 \mathrm{ka}$ for the loess on top of 'Stillfried A' in Paudorf (Paudorfer Bodenbildung). Immediately below this pedocomplex and equivalents to it, ages of $124 \pm 25$ ka (Göttweig-Aigen), $159 \pm 20 \mathrm{ka}$ (Paudorf 1), and $170 \pm 16 \mathrm{ka}$ (Joching) were obtained in loess.

Furthermore, there is evidence for older Middle Pleistocene deposits in Stratzing, Paudorf 2, Göttweig-Furth and Langenlois.
\end{abstract}

\section{[Löss-/Paläoboden Sequenzen in Niederösterreich im Licht neuer chronologischer Ergebnisse]}

Kurzfassung:

Der vorliegende Artikel gibt einen Überblick über neu datierte Abschnitte in bekannten Löss/Paläoboden-Sequenzen Niederösterreichs. Die Ergebnisse der Datierungen im Profil Joching deuten darauf hin, dass es im letzten Hochglazial zur Lösssedimentation kam. Die meisten erfassten Alter sind jedoch älter als das letzte Hochglazial, was auf Erosionsprozesse hindeutet, die zur Abtragung der jüngeren Lösse geführt hat.

In dem Abschnitt zwischen $\sim 28 \mathrm{ka}$ and $\sim 35 \mathrm{ka}$ wurden überwiegend Tundragleye gebildet. Eine intensivere interstadiale Bodenbildung ist nicht nachzuweisen. Dieses Ergebnis kann auch für die stratigraphische Einstufung von ,Stillfried B` (sensu Fink) von Bedeutung sein.

Der folgende chronologische Abschnitt liegt zwischen $~ 35$ ka and $~ 57$ ka in Lösssedimenten mit eingeschalteten Tundragleyen. Auch dieser Abschnitt ist durch Umlagerungsprozesse charakterisiert.

Im Zeitraum von $\sim 57$ ka bis $\sim 106$ ka befindet sich eine markante Zeitlücke, die vermutlich auf langandauernde und intensive Erosionsprozesse im Untersuchungsgebiet zurückzuführen ist.

Die älteste Datierung in den Sedimenten des letzten Glazials mit $106 \pm 12$ ka befindet sich in Paudorf direkt über dem ,Stillfried A'- Komplex (Paudorfer Bodenbildung). Direkt unter diesem Pedokomplex, bzw. vergleichbaren Pedokomplexen treten in Lössablagerungen Alter von $124 \pm 25 \mathrm{ka}$ (Göttweig-Aigen), $159 \pm 20 \mathrm{ka}$ (Paudorf 1), and $170 \pm 16 \mathrm{ka}$ (Joching) auf.

Darüber hinausgehende Alter konnten in Stratzing, Paudorf 2, Göttweig-Furth und Langenlois nachgewiesen werden.

Keywords:

Loess, Lower Austria, Luminescence dating, Paudorf, foching, Göttweig, Stratzing, Langenlois

Addresses of authors: B. Terhorst and T. Sprafke, University of Würzburg, Institute of Geography and Geology, Am Hubland, D-97074 Würzburg/ Germany. E-Mail: birgit.terhorst@uni-wuerzburg.de; C. Thiel and M. Frechen, Leibniz Institute for Applied Geophysics, S3: Geochronology and Isotope Hydrology, Stilleweg 2, D-30655 Hannover/Germany. E-Mail: Christine.thiel@liag-hannover.de; Manfred.frechen@liag-hannover.de; R. Peticzka, University of Vienna, Institute of Geography and Regional Research, Althanstr. 14, A-1090 Vienna/Austria. E-Mail: robert.peticzka@univie.ac.at; F. A. Fladerer, University of Vienna, Department of Palaeontology, Althanstr. 14, A-1090 Vienna/Austria. E-Mail: florian.Fladerer@univie.ac.at; R. Roetzel, Geological Survey of Austria, Neulinggasse 38, A-1030 Vienna/Austria. E-Mail: reinhard.roetzel@geologie.ac.at; C. Neugebauer-Maresch, Austrian Academy of Sciences, Prehistoric Commission, Fleischmarkt 22, A-1010 Vienna/Austria. E-Mail: christine.neugebauermaresch@oeaw.ac.at.

\section{Introduction}

Loess landscapes are widespread in Lower Austria. Especially the loess region adjacent to the eastern margin of the Bohemian Massif comprises famous loess sequences at Krems, Stratzing, Göttweig and Paudorf (Fig. 1). Equally important is the loess/paleosol sequence of Stillfried, which is situated further to the east.
Both regions have received much attention due to its archeological finds (e. g. ANTL-WEISER 1997; EINWÖGERER et al. 2006; HäNDEl et al. 2008; Neugebauer-MARESCH 2008).

However, the well-developed loess/paleosol sequences in Lower Austria have not experienced much attention besides archeological investigations since the works of FINK (1956, 1976, and 1978). Since the 1930's (GöTZINGER 1936) attempts have been made to develop a common stratigraphy 


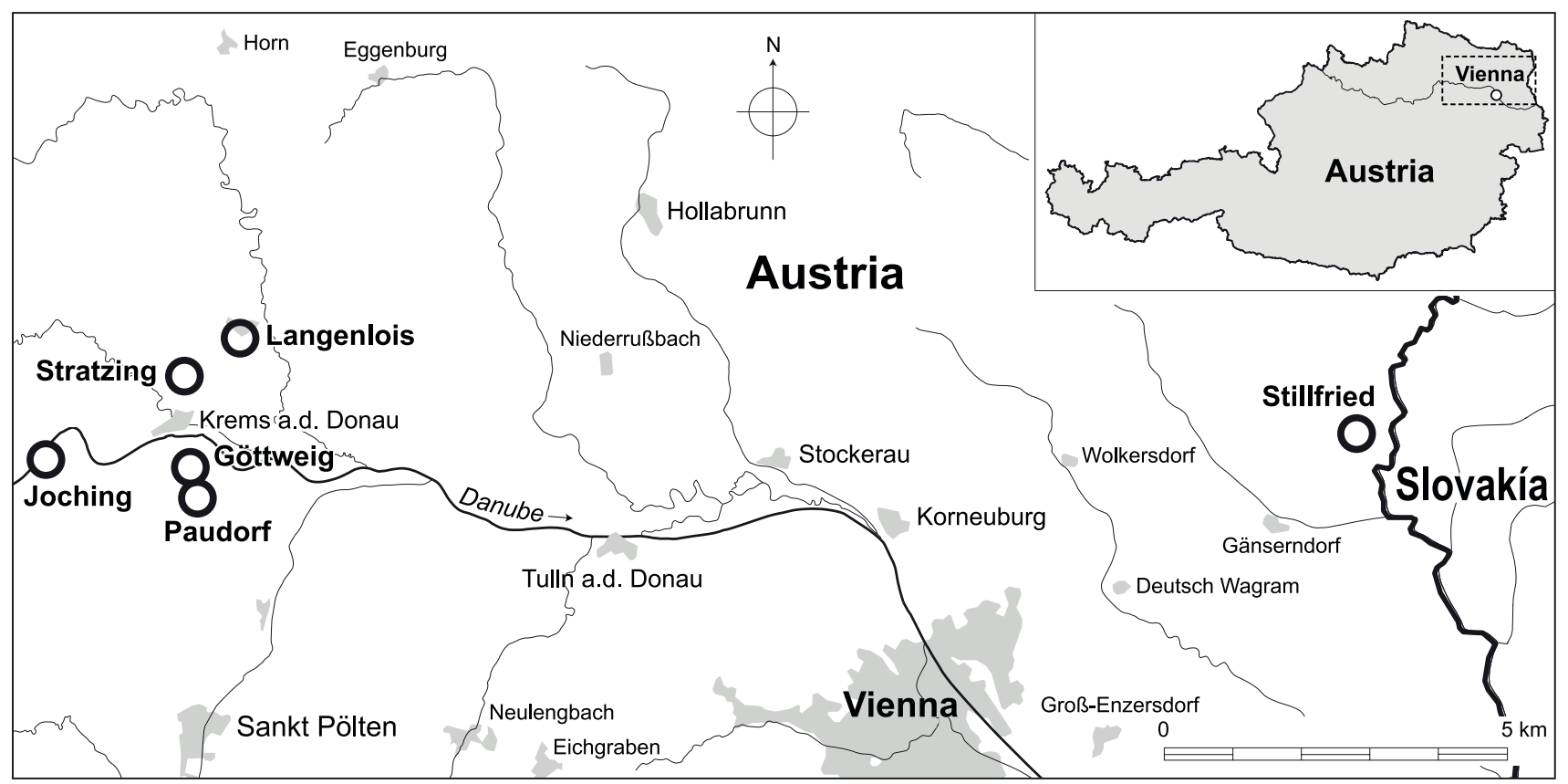

Fig. 1. Study sites in Lower Austria.

Abb. 1. Lage der untersuchten Profile in Niederösterreich.

for loess deposits in the area under study. This has not only been hampered by the lack of continuous records preserved but also by the lack of suitable dating techniques. Thus the chronological positions of many marker horizons such as the Stillfried complex (e.g. FINK 1976), the 'Göttweiger Verlehmungszone' and the 'Paudorfer Bodenbildung' (e.g. GÖTZINGER 1936; FINK 1976) have caused much controversy (e. g. Noll et al. 1994; ZöLLER et al. 1994). Until then it was not certain which of these pedocomplexes depicts the last interglacial soil (Eemian). Due to enhanced dating techniques THiEL et al. (2011a) were able to clearly identify the 'Paudorfer Bodenbildung' at its type locality in Paudorf as the Eemian soil (Fig. 1). The 'Göttweiger Verlehmungszone' can most likely be attributed to the marine isotope stage (MIS) 11 or any older interglacial (THIEL et al. 2011b). However, these results have only been a small step towards the reconstruction of the former landscape in Lower Austria and its evolution. Other approaches to gain more information on pedogenesis and paleoenvironmental conditions in Lower Austria during the Quaternary have included micromorphological (e.g. HAvLíčEK et al. 1998; SMOLÍKOvÁ 2003; SMOLÍKOVÁ \& HAVLÍČEK 2007), geochemical (HASLINGER ひ HEINRICH 2008; HASLINGER et al. 2009) and paleontological investigations (e.g. Frank \& RABEDER 1997; DöPPES \& RABEder 1997; Frank 1997; Fladerer et al. 2005). Due to topographically controlled variability of soil formation, the micromorpholocial attributes might not be sufficient to allow for stratigraphic correlations and numerical datings can complete the chronostratigraphy essentially.

Because Lower Austria is a geographical key position for the correlation of the dry loess landscape with the loess/paleosol sequences of east and south-east Europe, it is of great relevance to derive more information on loess deposition and paleopedogenesis as well as on erosion processes in time and space.

As an outline of current investigations in Lower Aus- tria, this study presents first chronological results in form of short summaries from the study sites in Stratzing, Joching, Stillfried, Paudorf, Göttweig, and Langenlois (Fig. 1). Detailed profile description, analytical results, and luminescence dating details have been published elsewhere (PeticzKa et al. 2010; Thiel et al. 2011a; b; c; 2011).

\section{The chronological framework of the loess/paleosol sequences}

\subsection{Stratzing}

The Stratzing loess/paleosol sequence (340 m a.s.l.) is situated at the eastern margin of the west-east elongated hill of the 'Galgenberg', which represents a characteristic landform in the loess area of the Kremser Feld (Fig. 1).

The loess/paleosol sequence of the Stratzing tennis court is exposed to a depth of $7.5 \mathrm{~m}$ and is subdivided in 19 units (Fig. 2: 1). Single thermoluminescence ages exist earlier from ZöLLER et al. (1994), detailed archeological investigations were conducted by Neugebauer-MAREsch (1993) in nearby excavations, and malacological results were presented by NIEDERHUBER (1997).

The basal part of the profile shows Middle Pleistocene loess deposits with an interglacial soil complex (ST18 and 19). The pedocomplex is covered by two loess layers (ST17) and a soil sediment (ST 16), which truncated the upper loess layer. Horizon ST 15 is the oldest archeological layer on top of which an alternating sequence of Cryosols and loess is visible (ST 14 to ST 6). This sequence exhibits two further archeological horizons (ST 13 and ST 10).

The uppermost part of the sequence consists of a loess layer (ST 5) and a well developed $1.0 \mathrm{~m}$ thick Cryosol pedocomplex (ST 4). The three uppermost horizons (ST 1-ST 3) are essentially disturbed by viticulture activities and are not described here. 
Luminescence dating was applied to nine horizons (THIEL et al. 2011a; see Table 1). Making use of a post-IR IRSL dating protocol, the loess below the pedocomplex ST 18 and ST 19 and also its overlying loess (ST 17) were dated to $>300 \mathrm{ka}$ (THIEL et al. 2011a). The colluvial layer (ST 16) indicates a hiatus, which is verified by an age of $117 \pm 8 \mathrm{ka}$ for horizon ST 15. ThIEL et al. (2011a) considered the obtained age as an overestimate due to post-depositional mixing. Both, the colluvial layer and the luminescence dating result imply a great discontinuity in the sequence. The sediment deposition of layer ST 14 was dated to $57 \pm 4 \mathrm{ka}$, and dating of ST 11 resulted in an age of $35 \pm 2 \mathrm{ka}$. The age of cultural layer I (ST 10 , sample 1627) was estimated to $32 \pm 2 \mathrm{ka}$; this is in good agreement with the radiocarbon ages (cluster) obtained for this cultural layer from a neighbouring outcrop (NEUGEBAUER-MARESCH 1993; see discussion in ThIEL et al. 2011a). For the loess layer (ST 5) a post-IR IRSL age of $31 \pm 2 \mathrm{ka}$ was obtained, and the overlying Cryosol complex (ST 4b) was dated to $28 \pm 2 \mathrm{ka}$.
Highly fragmented fossil horse remains have been saved from the basal parts of the sequence. They belong to both mandibles, two vertebrae, and the metatarsal III of the right body side. The measurements combined with the tooth morphology allow to identify the finds as Equus cf. mosbachensis, which is a strong signal of Middle Pleistocene age.

\subsection{Joching}

The study site is located on the left bank of the Danube valley in the Wachau, about $15 \mathrm{~km}$ west to the city of Krems, Lower Austria (Fig. 1). The valley is deeply incised in Paleozoic bedrock of the Bohemian Massif, the overlying Middle Miocene sediments, and its slopes are partly covered by loess and intercalated paleosols. The most famous site of the area is the archeological excavation of Willendorf. There, the loess and loess-like sediments are of Middle to Upper Pleistocene age, with uncalibrated ${ }^{14} \mathrm{C}$ ages rang-

Tab. 1: Compilation of the recently published ages on the base of luminescence and ${ }^{14} \mathrm{C}$-dating (STILLFRIED).

Tab. 1: Zusammenstellung der vor Kurzem publizierten Alter der Lumineszenz- und ${ }^{14}$ C-Datierungen (STILLFRIED).

\begin{tabular}{|c|c|c|c|}
\hline Site & Unit & Sample ID & Age [ka] \\
\hline \multirow{9}{*}{ Stratzing ${ }^{\mathrm{a}]}$} & ST4b & 1625 & $28 \pm 2$ \\
\hline & ST5 & 1626 & $31 \pm 2$ \\
\hline & ST10 & 1627 & $32 \pm 2$ \\
\hline & ST11 & 1628 & $35 \pm 2$ \\
\hline & ST14 & 1629 & $57 \pm 4$ \\
\hline & ST15 & 1630 & $117 \pm 8$ \\
\hline & ST17b & 1631 & $>300$ \\
\hline & ST19c & 1632 & $>300$ \\
\hline & ST19d & 1633 & $>300$ \\
\hline \multirow{3}{*}{ Joching $^{\text {b] }}$} & J1 & 1398 & $16 \pm 2$ \\
\hline & J3 & 1399 & $47 \pm 3$ \\
\hline & J9 & 1400 & $170 \pm 16$ \\
\hline \multirow[t]{2}{*}{ Stillfried } & S5 top & Hv 25618 & $24,430 \pm 730$ uncal. \\
\hline & S5 bottom & Hv 25619 & 22,840 \pm 870 uncal. \\
\hline \multirow[t]{4}{*}{ Paudorfb] } & P2-3 & 1402 & $187 \pm 12$ \\
\hline & P2-9 & 1401 & $189 \pm 16$ \\
\hline & P1-2 & 1404 & $106 \pm 12$ \\
\hline & P1-4 & 1403 & $159 \pm 20$ \\
\hline \multirow{5}{*}{ Göttweig ${ }^{\mathrm{b}}$} & G1-3 & 1405 & $>300$ \\
\hline & G1-1 & 1406 & $173 \pm 40$ \\
\hline & n.a. & 1407 & $>350$ \\
\hline & GII-1 & 1408 & $34 \pm 3$ \\
\hline & GII-4 & 1409 & $124 \pm 25$ \\
\hline \multirow[t]{6}{*}{ Langenlois ${ }^{\mathrm{c}]}$} & LB 2/9 & LB $2 / 9$ & $246 \pm 29$ \\
\hline & LB $2 / 10$ & LB 2/10 & $>300$ \\
\hline & LB 5/3 & LB $5 / 3$ & $35 \pm 2$ \\
\hline & LB 5/5 & LB 5/5 & $41 \pm 4$ \\
\hline & LB 5/10 & LB 5/10 & $41 \pm 4$ \\
\hline & LB 5/15 & LB 5/15 & $53 \pm 4$ \\
\hline
\end{tabular}


ing between $23,180 \pm 120$ and $41,700+3,700 /-2,500$ yrs. BP (Nigst et al. 2008).

The loess/paleosol sequence investigated has a total thickness of about $10 \mathrm{~m}$, with two distinct pedocomplexes (Fig. 2: 2). The basal loess deposit (J9) is covered by an interglacial pedocomplex (J6-J8). A silty yellowish-brown loess rich in secondary carbonates (unit J5) is exposed on the top of horizon J6. An interstadial paleosol (J4) is present on top of this loess, followed by stratified loamy brownish pellet sands ('Bröckelsande', unit J3). J2 corresponds to a zone of Cryic horizons (J2) (IUSS Working Group WRB 2006) and $\mathrm{J} 1$ represents the uppermost loess of the studied sequence.

At this site three luminescence samples were taken (Fig. 2; Thiel et al. 2011b). The lowermost loess unit (J9) was sampled $0.7 \mathrm{~m}$ below the pedocomplex (J7 and J8), and the post-IR IRSL dating resulted in an age of $170 \pm 16 \mathrm{ka}$ (Table 1). For the 'Bröckelsand' (J3; pellet sands) the depositional age was estimated to $47 \pm 3 \mathrm{ka}$. The uppermost sample originates from the loess unit J1 $1.3 \mathrm{~m}$ below the surface and was dated to $16 \pm 2 \mathrm{ka}$.

\subsection{Stillfried}

The Stillfried study site is located in a distance of about $40 \mathrm{~km}$ north-east the city of Vienna (Fig. 1). The study site comprises two famous loess/paleosol sequences. Both the 'Stillfrieder Komplex' and the profile of 'Stillfried B' are formed during the Last Glacial/Interglacial cycle. The Stillfried exposures were first mentioned by BoEHмкer (1917). He described the 'Stillfrieder Komplex' including three humic horizons superimposed on a Bt horizon. Furthermore, the key section of 'Stillfried B' is closely connected with the loess studies of the Austrian loess researcher Julius Fink. Repeatedly, he published on the characteristic weak brownish horizon with its significant content of charcoals (Fink 1954, 1956).

The 'Stillfried B' sequence has been dated repeatedly by radiocarbon dating due to the fact that numerous charcoals are included. The results of Fink (1962), VogeL \& ZAGwiJN (1967) and Rögl \& Summesberger (1978) are variable and provided partly age inversions. A more recent discussion is published in FLADERER (2001).

The presented sequence (Fig. 2: 6) is located in the western part of the abandoned brickyard of Stillfried at an altitude of $173 \mathrm{~m}$.

On top of loess strata (S6) three weakly developed BC horizons (S5) with an overall thickness of $1.2 \mathrm{~m}$ are situated on top of each other (PeTiczKA et al. 2010). The basal part of the pedocomplex shows marginally more intense pedogenesis as manifested in bioturbation structures. Charcoals occur in particular in the intermediate section of S5 as well as on top of the uppermost BC horizon (S4).

Recent radiocarbon dating results in a depth of $2.3 \mathrm{~m}$ (Hv 25618) respectively $2.6 \mathrm{~m}$ (Hv 25619), in a slight inversion of the uncalibrated ${ }^{14} \mathrm{C}$-dating (Table 1 ). The sample on top of the pedocomplex records an age of 24,430 $\pm 730 \mathrm{yr}$ (Hv 25618) and the lower sample is with 22,840 $\pm 870 \mathrm{yr}(\mathrm{Hv}$ 25619) at the same age, respectively slightly younger.

\subsection{Paudorf}

The village of Paudorf is located on the eastern foothills of the Bohemian massif, $7 \mathrm{~km}$ south to the city of Krems.

The studied sequences are exposed in a former brickyard and considered as the type locality of the 'Paudorfer Verlehmungszone' sensu Götzinger (1936) and Fink (1976), which was correlated with 'Stillfried A'. The outcrop, which is about $9.5 \mathrm{~m}$ deep (Fig. 2) has been described by FINK (1976) and KovANDA et al. (1995) and was analyzed with thermoluminescence by ZöLler et al. (1994) and NolL et al. (1994). The published ages differ from each other and do not allow a clear interpretation. At least two pedocomplexes are preserved at this site; the uppermost soil complex corresponds to the prominent 'Paudorfer Bodenbildung', and the basal pedocomplex was correlated with the 'Göttweiger Bodenbildung'.

In profile 1 (Fig. 2: 3a) the pedocomplex of the 'Paudorfer Bodenbildung' (P1/3), developed as a reddish-brown, clay-enriched pedocomplex with crotovina, is intercalated by loess sediments (P1/2 and P1/4).

Profile 2 (Fig. 2: 3b) exhibits a loess/paleosol sequence, which is subdivided in numerous layers and soil horizons, which have never been described in detail. According to Peticzka et al. (2009) a differentiation of at least five pedocomplexes and paleosols is possible. In the basal section of the profile, a well developed dark brown pedocomplex representing at least one interglacial period is present $(\mathrm{P} 2 / 10)$. It is overlain by yellowish brown carbonate-rich loess (P2/9) and a brownish paleosol horizon (P2/8). This horizon is overlain by the next loess strata (P2/3-7), which includes the horizons $\mathrm{P} 2 / 4$ and P2/6, which correspond to Cryosols (Reductaquic) according to the IUSS Working Group WRB (2006). Unit P2/2 corresponds to the pedocomplex 'Paudorfer Bodenbildung' described in profile Paudorf 1. In this position the soil horizons are situated close to the surface and thus are disturbed by recent bioturbation.

The position of the luminescence samples is specified in Fig. 2. The uppermost sample was taken in the loess unit P1/2 just above the 'Paudorfer Bodenbildung' (unit P1/3). The measurements of the uppermost sample on top of the 'Paudorfer Bodenbildung' resulted in an age of $106 \pm 12 \mathrm{ka}$ for unit P1/2 (Thiel et al. 2011b). The loess unit P1/4 below the 'Paudorfer Bodenbildung' was sampled as a block due to induration. The analyses recorded an age of $159 \pm 20 \mathrm{ka}$ (THIEL et al. 2011b).

In profile Paudorf 2, an age of $187 \pm 12$ ka was obtained for unit P2/3 $4.2 \mathrm{~m}$ below the surface $(\mathrm{P} 2 / 3)$, and the second sample, taken in the loess unit P2/9 (7.9 m below top ground surface), displays a rather similar age $(189 \pm 16 \mathrm{ka})$ (THIEL et al. 2011b). Both samples clearly indicate deposition during Marine Isotope Stage (MIS) 6. The underlying pedocomplex (P2/10) originally correlated with the 'Göttweiger Verlehmungszone’ (GöTzINGER 1936), thus developed during MIS 7 or an older interglacial.

\subsection{Göttweig}

The study site is situated $5 \mathrm{~km}$ south of the city of Krems and $2 \mathrm{~km}$ north to Paudorf (Fig. 1). Two different sections 


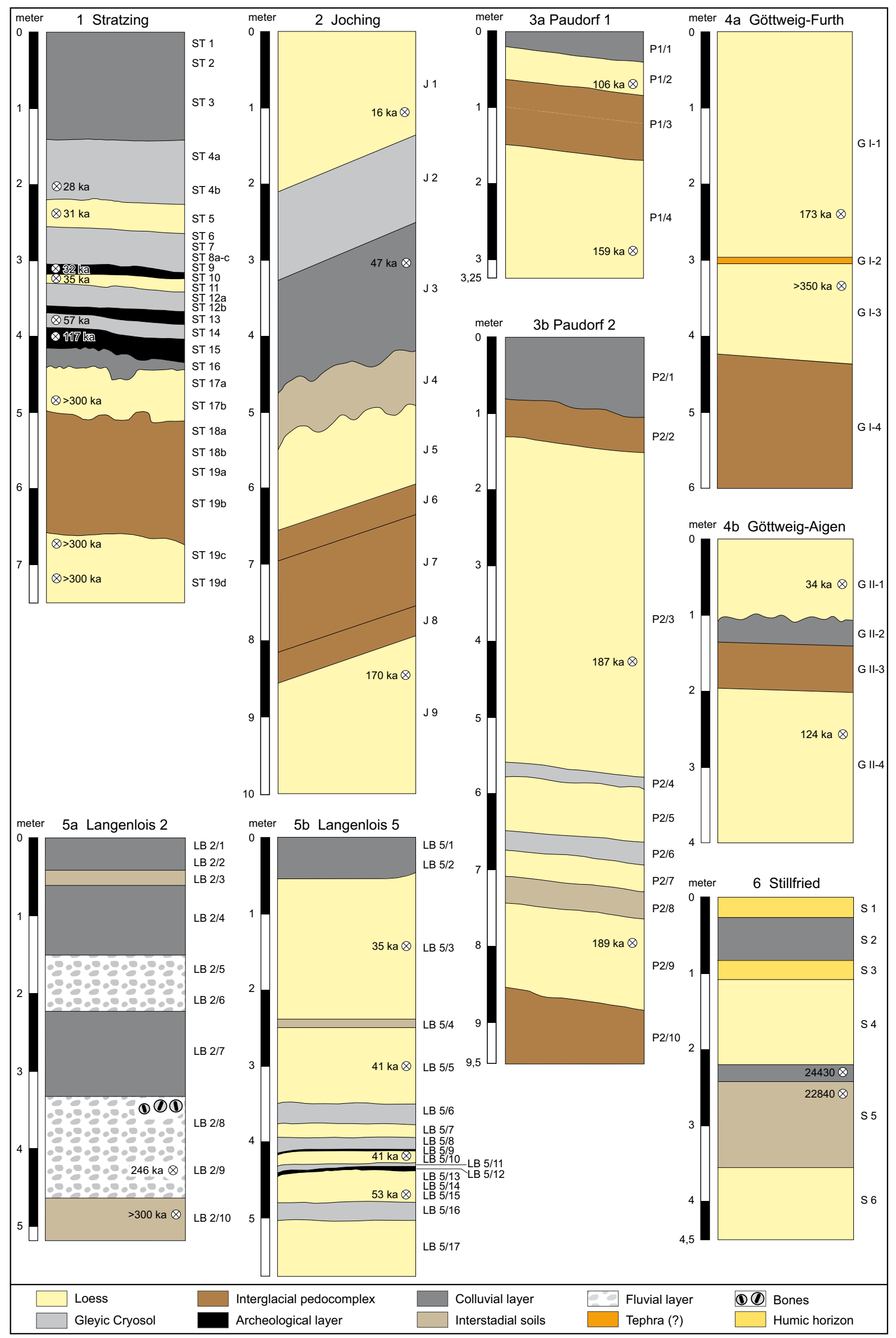

Fig. 2. Overview of the studied sequences on the base of field survey. The sketch provides a generalized and equalized view. The ages are simplified by not showing the errors; they can be depicted from the corresponding section and Table 1.

Abb. 2. Uberblick der untersuchten Profile auf der Basis der Geländeaufnahmen. Die Zeichnung gibt eine generalisierte und einander angepasste Sicht. Die Alter sind vereinfacht ohne Fehler dargestellt. Sie können den entsprechenden Unterkapiteln und Tabelle 1 entnommen werden. 
were investigated near the monastery of Göttweig, close to the loess sequence in Paudorf (Fig. 2: 4a and b). Section I, Göttweig-Furth (ca. $240 \mathrm{~m}$ a.s.l) represents the classical site of the 'Göttweiger Verlehmungszone' sensu BAYER (1927) and GöTzINGER (1936). It is located in a sunken path near the market town of Furth. On the section of GöttweigFurth, numerous studies have been published reflecting different opinions on the chronology of the pedocomplex 'Göttweiger Verlehmungszone'. For instance, FINK et al. (1976) classified the pedocomplex as Mindel/Riss Interglacial. Kovanda et al. (1995) proposed an older age and allocated it with respect to micromorphological analyses to an interglacial phase inside the Mindel complex. ZöLLER et al. (1994) allocated the 'Göttweiger Verlehmungszone' as at least antepenultimate interglacial.

With respect to the profile in Göttweig-Aigen, the results of ZöLLER et al. (1994) indicate that the sequence there belongs to the Last Glacial/Interglacial cycle.

In the section Göttweig-Furth (Fig.2: 4a) the pedocomplex 'Göttweiger Verlehmungszone' (unit GI-4) and the overlying up to $6 \mathrm{~m}$ thick sandy-silty yellowish-brown loess is horizontally exposed over several $100 \mathrm{~m}$ and situated on top of a Danube terrace of which the chronostratigraphical position is unclear. A continuous thin layer (unit GI-2) can be identified in the loess package; which has the appearance of a tephra. At present, a volcanic component could not be detected by mineralogical analyses.

The luminescence sampling points at Göttweig-Furth are shown in Figure 2 and Table 1. For the loess unit GI-3 (sample 1405) $0.3 \mathrm{~m}$ below the tephra band an age of $>350$ ka was obtained (ThiEL et al. 2011b; Table 1). The sample of the loess unit GI-1, $0.6 \mathrm{~m}$ above the tephra, was dated to $173 \pm 40 \mathrm{ka}$. About $300 \mathrm{~m}$ upslope of this section, a further sample (1407; not shown in Fig. 2) was taken just above the supposed tephra; dating resulted in an age $\geq 300 \mathrm{ka}$ (THIEL et al. 2011b).

The section Göttweig-Aigen is located in a sunken path near the village of Aigen, where a pedocomplex correlated with the 'Paudorfer Bodenbildung' is exposed (FINK 1976; Fig. 2: 4b). The pedocomplex (unit GII-3) is truncated in its upper parts, as indicated by the lack of an A horizon and a layer of $30 \mathrm{~cm}$ thick reworked loess (unit GII-2) covering the soil. Yellowish brown loess (GII-1) is present on top of the redeposited material and below the paleosol (GII-4).

The loess unit GII-1 (Table 1, sample 1408) $0.6 \mathrm{~m}$ above the 'Paudorfer Bodenbildung' was dated to $34 \pm 3 \mathrm{ka}$ (THIEL et al. 2011b). For the carbonate rich silty loess (unit GII-4), sampled $0.6 \mathrm{~m}$ below the 'Paudorfer Bodenbildung' (i.e. $2.45 \mathrm{~m}$ below top ground surface), an age of $124 \pm 25 \mathrm{ka}$ was obtained.

\subsection{Langenlois}

The study site is located about $7 \mathrm{~km}$ north-east to the city of Krems (Fig. 1) in the area of the Kremser Feld. The loess was deposited in a bay-like depression ('Kremser Bucht'), which was formed tectonically (WESSELY 2006). GöTZINGER (1936) made note of the up to $20 \mathrm{~m}$ thick loess sequences at the southern edge of the plateau, whereas PIffL (1955) observed even thicker loess deposition at the easterly slopes of the Kremser Feld. The north-exposed wall of the former brickyard in Langenlois was briefly described by
PIfFL (1976). In the former brickyard of Langenlois (Fig. 1), fluvial and aeolian deposits are present (PIFfL 1976). Until now, for the loess exposures around the market town of Langenlois only few data exist (SMOLÍKOvÁ 2003; FLADERER et al. 2005).

\section{Profile LB2: the fluvial sequence}

The sediment succession at the east exposed wall of the former brickyard in Langenlois clearly shows a transition from fluvial to eolian deposition (Fig. 2: 5a). The loamy deposits of LB 2/10 display a paleo-surface on which fluvial gravels and sands (LB 2/9 and LB 2/8) were deposited. The fluvial deposits of LB 2/8 include mammal bones, which are mostly in their original anatomical relationships. From a taphonomical point of view it is evident that sedimentation and deposition of carcasses of dead animals or their parts have taken place synchronously during very rapid channel sedimentation without significant relocation (THIEL et al. 2011c). The assemblage speaks in favour of interglacial conditions, but the actual status of taxonomic research does not allow a closer attribution than Middle Pleistocene.

The soil sediment LB $2 / 7$ is superimposed on the fluvial deposits of LB 2/8. It is covered by gravels and sands $L B$ 2/5-6, which reveal another fluvial deposit in the study area.

On top of LB 2/5 a redeposited loam is present (BL 2/4) overlain by a weak paleosol horizon (LB 2/3), which corresponds to an interstadial soil. The uppermost horizons are disturbed by intense land use.

Horizon LB 2/10 was dated to >300 ka (Thiel et al. 2011c; Table 1). The authors emphazised that the derived luminescence age is close to or even beyond the dating limit despite great improvements in latest dating techniques. Thus, a more accurate age cannot be presented. For the fluvial deposits (LB 2/9) luminescence dating resulted in an age of $246 \pm 29$ ka (Thiel et al. 2011c).

\section{Profile LB5: the eolian sequence}

The loess sequence is subdivided by three Cryosols (Reductaquic) (LB 5/6, LB 5/8, LB 5/16) indicating permafrost and associated retention of water (Fig.2: $5 \mathrm{~b}$ ). An initial soil horizon with a weak brownish color is present in the upper part of the sequence (LB 5/4).

A cultural layer containing charcoal fragments can be seen in the lower parts of the profile (LB 5/12).

The record ends with a thick loess strata situated below modern soil sediments.

The dating results indicate that the eolian sequence formed from $\sim 55 \mathrm{ka}$ until $\sim 35 \mathrm{ka}$ (ThiEL et al. 2011c; Table 1). The loess unit LB $5 / 15$ was dated to $53 \pm 4$ ka and for unit LB 5/10 an age of $41 \pm 4 \mathrm{ka}$ was obtained. The dating of the approximately $1 \mathrm{~m}$ thick homogenous loess of unit LB 5/5 resulted in the same age. The uppermost loess unit (LB 5/3) was dated to $35 \pm 2 \mathrm{ka}$.

\section{Discussion}

Upper to Middle Last Glacial ages have been obtained in the profiles of Joching, Stratzing and Stillfried. The youngest loess (16 $\pm 2 \mathrm{ka}$; Table 1$)$ was found in the upper parts of the sequence in Joching (Fig. 2). Such young loess is exceptional when compared with other loess/paleosol sequences 
in this area; the dating results indicate intense loess deposition between $\sim 28 \mathrm{ka}$ and $\sim 35 \mathrm{ka}$. Somewhat younger are the upper profile sections of Stillfried, which were dated by ${ }^{14} \mathrm{C}$ method. In Stillfried ages of $24,430 \pm 730 \mathrm{yr}$ BP and $22,840 \pm 870$ yr BP were obtained. Earlier TL-studies of ZöLLER et al. (1994) proved younger ages in the upper parts of the Stillfried B sequence.

Alltogether, the sequence in Joching clearly shows that there was loess deposition during the Upper Würmian Pleniglacial. Considering the somewhat older ages in other studied profiles, it can be assumed that erosional processes led to the removal of younger deposits.

Soil formation between $\sim 28 \mathrm{ka}$ and $\sim 35 \mathrm{ka}$ resulted in Cryosols, respectively. Hence, in the studied profiles, there is no evidence for more intense, interstadial pedogenesis in this time span. In the sequence of Willendorf, thin humic horizons are designated to interstadial periods (HAEsAERTS et al. 1996; NigST et al. 2008). However, there was proof of only one humic horizon in the sequence of Stratzing (THIEL et al. 2011a), which is not allocated to an interstadial period.

Related to the presented ${ }^{14} \mathrm{C}$-datings, the age of the paleosol complex in the key section of Stillfried B remains still unclear. It has to be discussed, that published datings are different from each other, measured with variable methods, and uncertainities in the position of samples and sample preparation have to be considered as well. In general ${ }^{14} \mathrm{C}$-datings are not calibrated in the literature and thus hardly comparable to luminescence results.

However, in Upper Austrian loess profiles there is evidence of intens interstadial pedogenesis at about $29 \mathrm{ka}$ (Terhorst et al. 2002).

The following age cluster lies in the Middle Pleniglacial between $\sim 35 \mathrm{ka}$ and $\sim 57 \mathrm{ka}$ and in that case, one can find primarily loess sediments. Weak and thin Cryic horizons and the loess layers provide evidences for a cold glacial climate.

Furthermore, a prominent colluvial layer in form of pellet sands is present in Joching ( $47 \pm 3 \mathrm{ka}$ ). It is underlain by an interstadial brown paleosol of unknown age.

At the sequence in Stratzing differences between former radiocarbon datings and latest luminescence ages are observed. The discrepancy for the central part of the profile (ST 14 and ST 15) is due to redeposition processes and incorporation of older soil material in the slope position. In this context, it has to be highlighted that luminescence dating techniques constrain the time of deposition of sediment, whereas radiocarbon ages refer to the death of an organism. The sediment can therefore be older than incorporated, anthropogenic buried charcoal, wood or artifacts. Controversy may also have arisen because neighboring outcrops were dated, and thus a correlation of individual horizons is hampered.

For the investigations the absence of ages between $\sim 55 \mathrm{ka}$ and $\sim 106 \mathrm{ka}$ it is indicative and might record long lasting and intensive erosion processes in the loess landscape. An age of $106+/-12 \mathrm{ka}$ was obtained from the loess on top of the 'Paudorfer Bodenbildung' (THIEL et al., 2011b), which is equivalent to the Stilllfried A complex. Immediately below this pedocomplex ages of $124 \pm 25 \mathrm{ka}$ (Göttweig-Aigen), $159 \pm 20 \mathrm{ka}$ (Paudorf 1), and $170 \pm 16 \mathrm{ka}$ (Joching) were obtained for the loess.

Other sediments older than MIS 5 but younger than MIS 7 were detected in Göttweig-Furth and Paudorf 2.

Concerning the older sediments there are discontinuities, which might be due to the low sampling resolution. However, it is also evident that Lower Austrian loess sequences exhibit great hiatus as shown in Stratzing and Göttweig-Aigen (see HAvLIČEK et al. 1998).

The sequence Langenlois 2 shows an age of $246 \pm 50 \mathrm{ka}$ in its basal fluvial deposits. This age is close to the beginning of MIS 7 (LisIECKI \& RAYMo 2005) and gives an approximation for the faunal remains at this site, which stand for forest to park-like paleoenvironmental conditions and might reflect the beginning of an interglacial (THIEL et al. 2011c).

The next older dating results stand for minimum ages in the range of the given constraints of the dating method. Stratzing and Langenlois record ages of $>300 \mathrm{ka}$ for the basal parts, and Göttweig is with an result of $\geq 350$ ka in consistence with older age estimates of KovANDA et al. (1994).

All gathered information in the study sites give evidence of numerous and intensive land forming processes in form of erosion and redeposition.

\section{References}

Antl-Weiser, W., Fladerer, F.A., Peticzka, R., Stadler, F.C. ひ Verginis, S. (1997): Ein Lagerplatz eiszeitlicher Jäger in Grub bei Stillfried. Archäologie Österreichs, 8/1: 4-20.

BAYER, J. (1927): Der Mensch im Eiszeitalter, I. und II. Teil. - Wien (Deutike) BöнмкеR, R. (1917): Exkursionsführer für Stillfried an der March. p. 13-59, Braunmüller, Wien.

Döppes, D. \& Rabeder, G. (1997): Pliozäne und pleistozäne Faunen Österreichs. - Mitteilungen der Kommission für Quartärforschung der Òsterreichischen Akademie der Wissenschaften, 10: 1-411.

Einwögerer, T., Friesinger, H., Händel, M., Neugebauer-Maresch, C., Simon, U. \& Teschler-Nicola, M. (2006): Upper Paleolithic infant burials. - Nature, 444: 285.

Fink, J. (1954): Die fossilen Böden im österreichischen Löss. - Quartär, 6 85-108.

FINK, J. (1956): Zur Korrelation der Terrassen und Lösse in Österreich. Eiszeitalter und Gegenwart, 7: 49-77.

FinK, J. (1962): Studien zur absoluten und relativen Chronologie der fossilen Böden in Österreich. II; Weitzelsdorf und Stillfried. - Archaeologia Austriaca, 31: 1-18.

FINK, J. (1976): Exkursion durch den österreichischen Teil des nördlichen Alpenvorlandes und den Donauraum zwischen Krems und Wiener Pforte. Erweiterter Führer zur Exkursion aus Anlass der 2. Tagung der IGCP-Projektgruppe „Quaternary Glaciations in the Northern Hemisphere". - Mitteilungen der Kommission für Quartärforschung der Österreichischen Akademie der Wissenschaften, 1: 1-113.

FINK, J. (1978): Exkursion durch den österreichischen Teil des nördlichen Alpenvorlandes und den Donauraum zwischen Krems und Wiener Pforte. Ergänzungen zu Band 1. - Mitteilungen der Kommission für Quartärforschung der Österreicher Akademie der Wissenschaften, Wien.

Fladerer, F. A. (2001): Die Faunareste von Krems-Wachtberg, Ausgrabung 1930. Jagdwild und Tierkörpernutzung an der Donau vor 27.000 Jahren. - Mitteilungen der Prähistorischen Kommission der Österreichische Akademie der Wissenschaften, Phil.-hist. Kl., 39: 1-97.

Fladerer, F.A., Havlíček, P., Roetzel, R., Salcher, T., Smolíková, L. \& TuzAR, J. (2005): Der Steppenwisentfund (Bison priscus) von Langenlois-Buriweg, Niederösterreich - Paläontologische und pleistozänstratigrafische Untersuchungen. - Mitteilungen der Kommission für Quartärforschung der Österreichische Akademie der Wissenschaften, 14: $29-40$.

Frank, C. (1997): Stillfried-Typusprofile. In: Döppes, D. \& Rabeder, G (Eds.): Pliozäne und pleistozäne Faunen Österreichs. - Mitteilungen der Kommission für Quartärforschung der Österreichischen Akademie der Wissensenschaften, 10: 123-130, Verlag der Österreichischen Akademie der Wissenschaften, Wien.

Frank, C. \& RABEDER, G. (1997): Klimageschichte des österreichischen Plio-Pleistozäns. In: Döppes, D. \& RABEder, G. (Hrsg.): Pliozäne und pleistozäne Faunen Österreichs. - Mitteilungen der Kommission für 
Quartärforschung der österreichischen Akademie der Wissenschaften, 10: 375-380.

Götzinger, G. (1936): Das Lößgebiet um Göttweig und Krems an der Donau. - Führer für die Quartär-Exkursionen in Österreich, 1: 1-11.

Haesaerts, P., Damblon, F., Bachner, M. \& Trnka, G. (1996): Revised stratigraphy and chronology of the Willendorf II sequence, Lower Austria. - Archaeologia Austriaca, 80: 25-42.

Händel, M., Simon, U., Einwögerer, T. \& Neugebauer-Maresch, C. (2008): Loess deposits and the conservation of the archaeological record. The Krems-Wachtberg example. - Quaternary International, 198: 46-50.

Haslinger, E. \& Heinrich, M. (2008): Der „Rote Aufschluss“ von Langenlois. Pedogenese und Mineralogie von Paläoboden-Sequenzen über Amphibolit. - Abhandlungen der Geologischen Bundesanstalt Wien, 62: 71-79.

Haslinger, E., Smoliková, L., Havliček, P., Roetzel, R., Heinrich, M., HoláseK, O., VAcheK, M. \& OtTner, F. (2009): Pedological and geochemical investigations at the"Red Outcrop" of Langenlois (Lower Austria). - E\&G Quaternary Science Journal, 58(2): 135-147.

Havliček, P., Holásek, O., Smolíková, L., Roetzel, R. (1998): Zur Entwicklung der Quartärsedimetne am Südostrand der Böhmischen Masse in Niederösterreich. - Jahrbuch der Geologischen Bundesanstalt, 141: 51-72.

IUSS WorkING Group WRB (2006): World Reference Base for Soil Resources. - World Soil Resources Reports, 103p. FAO, Rome

KovandA, J., SMOLí́KovÁ, L. ¿ HoráčEK, I. (1995): New data on four classic loess sequences in Lower Austria. - Antropozoikum, 22: 63-85.

LisIecki, L. E. ¿ RAYMO, M. E. (2005): A Pliocene-Pleistocene stack of 57 globally distributed benthic $\delta 18 \mathrm{O}$ records. - Paleoceanography, 20: $1-17$.

Niederhuber, M. (1997): Stratzing/Krems-Rehberg. - In: Döppes, D. d RABEDER, G.: Pliozäne und pleistozäne Faunen Österreichs. Mitteilungen der Kommission für Quartärforschung der Österreichischen Akademie der Wissenschaften, 10: 56-61.

NeugEBAUER-MARESCH, C. (1993): Zur altsteinzeitlichen Besiedlungsgeschichte des Galgenberges von Stratzing/Krems-Rehberg. - Archäologie Österreichs, 4: 10-19.

Neugebauer-Maresch， C. (ed.) (2008): Krems-Hundssteig - Mammutjägerlager der Eiszeit. Ein Nutzungsareal paläolithischer Jägerund Sammler(-innen) vor 41.000-27.000 Jahren. - Mitteilungen der Prähistorischen Kommission der Österreichischen Akademie der Wissenschaften, 67: $348 \mathrm{pp}$.

Nigst, P. R., Viola, T.B., Haesaerts, P. \& Trnka, G. (2008): Willendorf II. - In: Venus08 - Art and Lifestyle, Symposium Vienna 10.-14. November 2008. - Wissenschaftliche Mitteilungen aus dem Niederösterreichischen Landesmuseum, 19: 31-58.

Noll, M., Leitner-Wild, E. \& Hille, P. (1994): Thermoluminescence dating of loess deposits at Paudorf, Austria. - Quaternary Geochronology (Quaternary Science Reviews), 13: 473-476.

Peticzka, R., Riegler, D. \& Holawe, F. (2009): Exkursionsführer der 28 Jahrestagung des Arbeitskreises Paläopedologie der Deutschen Boden- kundlichen Gesellschaft. Universität Wien (unpublished; http://www. dbges.de/wb/pages/arbeitsgruppen/palaeopedologie/aktivitaeten.php).

Peticzka, R., Holawe, F., Riegler, D. (2010): Structural analyses on the modified paleosol-sequence of "Stillfried B" with high resolution measurements of selected laboratory parameters. - Quaternary International, 222: 168-177.

Piffl, L. (1955): Exkursion von Krems bis Absberg. - Verhandlungen der Geologischen Bundesanstalt, Sonderheft: 70-78.

Piffl, L. (1976): Stop 3/4: Ziegelwerk W Langenlois (Hammerer). - In: Fink, J. (ed.): Exkursion durch den österreichischen Teil des nördlichen Alpenvorlandes und den Donauraum zwischen Krems und Wiener Pforte. Erweiterter Führer zur Exkursion aus Anlass der 2. Tagung der IGCP-Projektgruppe „Quaternary Glaciations in the Northern Hemisphere". - Mitteilungen der Kommission für Quartärforschung der Österreichischen Akademie der Wissenschaften, 1: 113 pp.

Rögl, F. \& Summesberger, H., (1978): Die geologische Lage von Stillfried. - Forschungen in Stillfried, 3: 75-86.

SmolíkovÁ, L. (2003): Bericht 2002 über Mikromorphologie, Typologie und Stratigraphie quartärer Böden vom Buriweg in Langenlois auf Blatt 38 Krems. - Jahrbuch der Geologischen Bundesanstalt, 143/3: 506-507.

SMolíkovÁ, L. ¿ HavlíčEK, P. (2007): Bericht 2005 und 2006 über mikromorphologische Untersuchungen von quartären Böden im Gebiet des unteren Kamptales auf den Blättern 21 Horn und 38 Krems. - Jahrbuch der Geologischen Bundesanstalt, 147/3-4: 682-683.

Terhorst, B., Frechen, M. \& Reitner, J. (2002): Chronostratigraphische Ergebnisse aus Lößprofilen der Inn- und Traun-Hochterrassen in Oberösterreich. - Zeitschrift für Geomorphologie N.F., 127: 213-232.

Thiel, C., Buylaert, J.-P., Murray, A. S., Terhorst, B., Hofer, I., TsuKAMOTO, S. \& FreChEN, M. (2011a): Luminescence dating of the Stratzing loess profile (Austria) - Testing the potential of an elevated temperature post-IR IRSL protocol. - Quaternary International, 234: 23-31.

Thiel, C., Buylaert, J.-P., Murray, A. S., Terhorst, B., Tsukamoto, S. \& FRECHEN, M. (2011b): Investigating the chronostratigraphy of prominent palaeosols in Lower Austria using post-IR IRSL dating. - E\&G Quaternary Science Journal, accepted.

Thiel, C., Terhorst, B., Jaburová, I., Buylaert, J.-P., Murray, A. S., Fladerer, F. A., Damm, B., Frechen, M. \& Ottner, F. (2011c): Sedimentation and erosion processes in Middle to Late Pleistocene sequences exposed in the brickyard of Langenlois/Lower Austria. Geomorphology. DOI 10.1016/j.geomorph.2011.02.011.

VogeL, J. C. \& ZAGWIJN, W. H. (1967): Groningen radiocarbon dates VI. Radiocarbon, 9: 63-106.

Wessely, G. (2006): Geologie der österreichischen Bundesländer, Niederösterreich. - 416 S., Wien (Geologische Bundesanstalt).

ZöLler, L., Oches, E.A., McCoy, W.D. (1994): Towards a revised chronostratigraphy of loess in Austria with respect to key sections in the Czech Republic and in Hungary. - Quaternary Geochronology (Quaternary Science Reviews), 13: 465-472. 